\title{
ANALISIS FAKTOR-FAKTOR YANG MEMPENGARUHI METODE AKUNTANSI PERSEDIAAN PADA PERUSAHAAN MANUFAKTUR YANG TERDAFTAR DI BURSA EFEK INDONESIA (BEI)
}

\author{
Oleh \\ Romasi Lumban Gaol
}

\begin{abstract}
Abstrak
Tujuan penelitian adalah untuk memperoleh bukti empiris mengenai faktor-faktor yang mempengaruhi pemilihan metode akuntansi persediaan. Faktor-faktor yang mempengaruhi metode akuntansi persediaan yang merupakan variable independen adalah stuktur kepemilikan, ukuran perusahaan, variabilitas persediaan, intensitas persediaan dan intensitas modal, sedangkan variable dependent adalah metode akuntansi, yaitu metode rata-rata dan metode FIFO. Perusahaan Manufaktur yang listing di Bursa Efek Indonesia dari tahun 2006-2009 merupakan objek dalam penelitian ini. Penelitian ini dilakukan dalam rentang waktu 4 tahun dari taun 2006 sampai dengan tahun 2009. Pengujian terhadap hipotesis dilakukan secara univariate dengan uji beda rata-rata (t-test) dan multivariate dengan regresi logistik. Pengujian menggunakan tingkat singnifikan sebesar $5 \%$. Hasil pengujian dengan regresi logistik mendapatkan bahwa variabel stuktur kepemilikan, variabilitas persediaan dan intensitas persediaan berpengaruh secara singnifikan terhadap metode akuntansi persediaan. Sedangkan ukuran perusahaan dan intensitas modal tidak berpengaruh secara singnifikan terhadap pemilihan akuntansi persediaan. Hasil uji beda rata-rata mendapatkan bahwa variabel struktur kepemilikan dan ukuran perusahaan antara metode akuntansi berbeda secara singnifikan. Tetapi tidak ada perbedaan yang singnifikan antara metode akuntansi persediaan FIFO dengan merode rata-rata dilihat dari variabilitas persediaan, intensitas persediaan dan intensitas modal. Disarankan bagi para menejer agar dapat mempertimbangkan variabel-variabel yang telah diteliti tersebut dalam pemilihan metode penilaiaan akuntansi persediaan.
\end{abstract}

Kata Kunci : Metode Akuntansi Persediaan, Average dan FIFO

\section{PENDAHULUAN}

Kebijakan metode penilaian persediaan akan mempengaruhi kandungan informasi yang disajikan dalam laporan keuangan, baik dalam neraca maupun laporan laba/rugi. Pemilihan metode penilaian persediaan untuk pelaporan keuangan di Indonesia diatur dalam Pernyataan Standar Akuntansi Keuangan (PSAK) 14. Di dalam PSAK 14 (2004) disebutkan bahwa pihak perusahaan diberi kebebasan untuk menentukan metode penilaian persediaannya, baik FIFO, rata-rata, maupun LIFO. Namun untuk memenuhi kebutuhan fiskal, berdasarkan Undang-Undang $\mathrm{PPh}$ No. 36 Tahun 2008 dan juga berdasarkan PSAK 14 (Revisi 2008), pihak 
perusahaan hanya diperbolehkan untuk menerapkan metode penilaian persediaan FIFO dan rata-rata.

Pertimbangan dalam metode mana yang harus diterapkan perusahaan menimbulkan konflik kepentingan antara manajemen, pemilik dan pemerintah. Namun demikian, pertimbangan rasional yang diambil manajemen untuk memilih metode akuntansi persediaan adalah maksimalisasi nilai perusahaan (Lindahl, 1989) atau meminimalkan pajak untuk memperoleh tax saving yang besar dengan tetap berpegang pada kendala-kendala yang ada yaitu hukum pajak dan kesempatan produksiinvestasi (Lee dan Hsieh, 1985).

Dalam analisa pemilihan metode akuntansi persediaan terdapat beberapa factor yang mempengaruhi metode pemilihan tersebut yaitu variabel persediaan, ukuran perusahaan, leverage, margin laba kotor, variable laba akuntansi, intensitas modal, intensitas persediaan, variabel harga pokok penjualan, dan ratio lancar. (Abdullah dan Djalil, 2004 \& Mukhlasin, 2002)

Penelitian yang dilakukan terhadap pemilihan metode persediaan di Indonesia menunjukkan bahwa perusahaan-perusahaan pada umumnya menggunakan metede rata-rata dan metode FIFO. Hal ini disebabkan karena tujuan pajak sebagaimana yang diatur pada Undang-Undang PPh No. 36 Tahun 2008 metode yang diperbolehkan adalah metode FIFO dan metode rata-rata. Apabila suatu perusahaan dalam laporan keuangan menggunakan metode LIFO dan metode idantifiksasi khusus maka untuk tujuan pajak harus membuat lagi dengan metode yang diperbolehkan yaitu metode rata-rata dan FIFO. (Gunadi,1998).

Beberapa penelitian yang terkait dengan pemilihan metode penilaian persediaan telah dilakukan sebelumnya. Penelitian tersebut antara lain penelitian Salma (2001) dan Mukhlasin (2001). Penelitian tersebut samasama meneliti tentang faktor-faktor yang mempengaruhi pemilihan metode akuntansi persediaan pada perusahaan Manufaktur yang terdaftar di Bursa Efek Jakarta (BEJ), akan tetapi penelitian tersebut meneliti variable yang berbeda. Variable yang diteliti pada penelitian Salma yakni: struktur kepemilikan, financial leverage, ukuran perusahaan, variabilitas persediaan, dan rasio lancar. Sedangkan penelitian yang dilakukan oleh Mukhlasin yaitu: variabilitas persediaan, variabilitas laba akuntansi, ukuran perusahaan, intensitas modal, intensitas persediaan dan variabilitas harga pokok penjualan.

Penelitian yang dilakukan oleh Salma (2001) dengan periode penelitian 1997-2000 ternyata memberikan hasil yang singnifikan pada 
variable variabilitas persediaan dan ukuran perusahaan mempengaruhi pemilihan metode akuntansi persediaan. Untuk variable struktur kepemilikan, financial leverage dan rasio lancar memberikan hasil bahwa variable tersebut tidak singnifikan mempengaruhi pemilihan metode akuntansi persediaan.

Penelitian ini merupakan pengembangan dari penelitian sebelumnya yang juga menganalisis faktor-faktor yang berpengaruh dalam pemilihan metode penilaian persediaan. Faktor-faktor yang terpilih sebagai variabel independen sebanyak lima variabel, yaitu struktur kepemilikan, ukuran perusahaan, variabilitas persediaan, intensitas persediaan dan intensitas modal.

Masalah yang diteliti dirumuskan dalam bentuk pertanyaan sebagai berikut: Apakah struktur kepemilikan, ukuran perusahaan, variabilitas persediaan, intensitas persediaan dan intensitas modal akan mempengaruhi pemilihan metode akuntansi persediaan?

\section{TELAAH TEORI}

\section{Telaah Teori}

\section{a. Teori Agensi}

Jensen dan Meckling (1993) menyatakan bahwa perusahaan adalah "fiksi legal yang bertindak sebagai suatu kelompok (nexus) kontrak untuk seperangkat hubungan diantara individu". Hubungan yang dimaksud adalah hubungan sebagai kontrak yang satu atau lebih (principal) memimta orang lain (agent) untuk melakukan beberapa kegiatan (service) atas kepentingan yang meliputi pendelegasian beberapa otoritas pengambilan keputusan pada agen. Dalam kaitannya dengan pemilihan metode akuntansi persediaan Lee dan Hsieh (1985) menyatakan bahwa manajer akan memilih metode perediaan berdasarkan pada contractual didalam lingkungan perusahaan.

\section{b. Hipotesis Ricardian (hipotesis pajak)}

Classical Ricardian menyatakan bahwa manajer bertujuan tunggal untuk memaksimalkan nilai perusahaan, dengan meminimalkan biaya pajak serta tetap respek pada kendala hukum pajak dan kesempatan produksi invetasi (Lee dan Hsieh, 1985). Dalam kaitanya dengan metode persediaan More dan Richardson (1983) mengemukakan bahwa karena metode persediaan mempengaruhi pajak penghasilan, manajer perusahaan 
mempertimbangkan pengaruh pajak ketika memutuksn untuk memilihnya. Sementara itu Watts dan Zimmerman (1986) mengemukakan bahwa pengaruh potensial pajak mempengaruhi pemilihan prosedur akuntansi. Untuk perusahaan dengan kesempatan produksi investasi yang heterogen, manajer yang mempunyai nilai (maksimal) akan mengadopsi metode akuntansi persediaan menurut keunggulan komparatif yaitu dapat meminimalisir biaya pajak ( Lee dan Hsieh, 1985)

\section{c. Political Cost}

Scott (1997) menyatakan bahwa biaya politik yang dihadapi manajer lebih besar, manajer lebih menyukai memilih prosedur akuntansi yang melaporkan earning berbeda dari periode sekarang dengan periode yang akan datang. Scott mencontohkan "political cost dibebankan pada perusahaan dengan profitabilitas yang tinggi akan menarik perhatian media dan konsumen". Lee dan Hsieh (1985) menyebutkan bahwa perbedaan jumlah akuntansi dari perbedaan metode akuntansi akan memicu tindakan politik. Dengan demikian dalam kaitannya dengan pemilihan metode akuntansi persedian, manajemen akan memilih metode yang memberikan political cost yang rendah yaitu mempunyai probabilitas yang rendah, hal ini disebabkan jika perusahaan memiliki probabilitas yang tinggi akan menarik perhatian media dan konummen sehingga political costnya semakin besar.

\section{Pengembangan Hipotesis}

a. Struktur kepemilikan

Struktur kepemilikan ditunjukkan dari besarnya kepemimpinan (manajer) suatu perusahaan oleh pemilik perusahaan (shereholder) tersebut. Manajer merupakan pengelola perusahaan yang dipercayai oleh shereholder. Sehubungan dengan pemilihan metode akuntansi persediaan maka antara manajer dengan pemilik timbul konflik kepentingan (agency theory). Masing-masing pihak, yaitu manajer dan pemilik akan berusaha memaksimalkan kesejahteraannya masing-masing.

Apabila manajer memiliki persentase kepemilikan saham yang kecil pada suatu perusahaan maka manajer mempunyai kecenderungan memilih metode yang memberikan laba yang lebih besar agar bonus yang akan diterima juga menjadi besar. Dengan demikian kesejahteraan manajer menjadi tujuan utama dalam pemilihan metode persediaan. Sebaliknya apabila manajer memiliki saham dengan persentase yang relatif besar, 
maka manajer akan memilih metode yang bisa memperoleh penghematan pajak (tax saving).

Penelitian yang dilakukan oleh Niehaus (1989) memberikan bukti tentang adanya hubungan yang singnifikan antara struktur kepemilikan dengan pemilihan metode akuntansi. Semakin besar kepemilikan manejer maka konfik yang terjadi semakin kecil. Sedangkan penelitian yang dilakukan oleh Salma (2001) memberikan hasil yang berbeda dengan Niehaus (1989). Menurut Salma (2001) tinggi atau rendahnya persentase kepemilikan saham oleh manajer, tidak akan mempengaruhi pemilihan metode akuntansi persediaan.

\section{b. Ukuran Perusahan}

Ukuran perusahaan merupakan proksi volatilitas oprasional dan Inventory controllability yang seharusnya dalam skala ekonomis, besarnya perusahaan menunjukkan pencapaian operasi lancar dan pengendalian persediaan (Lee dan Hsieh, 1985). Selain itu besarnya perusahaan juga menunjukkan kemampuaan perusahaan untuk mengalokasikan sumber daya pada aktivitsa perusahaan.

Watts Zimmermen (1986) menyatakan bahwa jika perusahaan sensitif terhadap variasi ukuran perusahaan, perusahaan yang lebih besar lebih menyukai prosedur (metode) akuntansi yang dapat menunda pelaporan earning. Perusahaan besar relatif lebih sensitif dibandingkan dengan perusahaan kecil. Kondisi ini ada dengan asumsi bahwa perusahaan sensitivitasnya lebih besar dan transfer kekayaan secara relatif lebih besar dibebankan dibandingkan dengan perusahaan kecil.

Kecendrungan metode akuntansi persediaan yang digunakan perusahaan besar adalah metode rata-rata yang bisa menurunkan laba. Penggunaan metode rata-rata selain bisa menurunkan biaya politik (political cost) juga memperoleh penghematan pajak (tax savung). Dana dari perusahaan besar umumnya diperoleh dari investor dan investor lebih menyukai perusahaan dengan pajak yang lebik kecil. Sedangkan pada perusahaan kecil, untuk mendapatkan dana dari bank atau lembaga keuangan lainnya membutuhkan laba yang tinggi agar dianggap mempunyai kinerja yang bagus. Salah satu cara untuk menaikkan laba dengan kecendrungan menggunakan metode akuntansi persediaan FIFO.

Penelitian Salma (2001) dan Mukhlasin (2001) menunjukkan hasil yang singnifikan mengenai hubungan ukuran perusahaan dengan pemilihan metode akuntansi persediaan. Perusahaan besar akan lebih memilih metode akuntansi yang dapat menurunkan laba. 


\section{c. Variabilitas Persediaan}

Nilai persedian akhir dalam sebuah perusahaan sangat variatif sekali, variasi ini menggabarkan operasionalisasi perusahaan yang mencerminkan tehnik persediaan dan akuntansi persediaan serta pergerakan persediaan itu sendiri (Lee dan Hsieh, 1985). Variabilitas persediaan menggambarkan variasi penyajian nilai persediaan akhir dalam neraca, variabilitas yang tinggi menunjukkan bahwa penyajian persediaan heterogen, hal ini ditunjukkan oleh metode FIFO yang berarti terjadi variasi persediaan akhir, sedangkan metode LIFO menghasilkan variabilitas yang rendah (homogen). Dengan kata lain LIFO akan menghasilkan nilai persediaan yang lebih smoothing dibandingkan dangan metode FIFO.

Variabilitas persediaan antara metode FIFO dibandingkan dengan metode rata-rata memang tidak kontradiktif. Metode akuntansi persediaan rata-rata mempunyai variabilitas yang relatif lebih stabil dibanding dengan FIFO. Sebagaiman yang dikemukakan oleh Tuanakotta (2000) bahwa metode rata-rata tertimbang sebenarnya bersifat netral terhadap inventory dan cost of good sold.

Penelitian yang dilakukan oleh Salma (2001) membuktikan bahwa variabilitas persediaan mempunyai pengaruh yang singnifikan terhadap pemilihan metode akuntansi persediaan. Hasil ini berlawanan dengan penelitian yang dilakukan oleh Mukhlasin (2001) yang menyatakan bahwa tidak menemukan hasil yang singnifikan untuk variable variabilitas persediaan terhadap pemilihan metode akuntansi persediaan. Abdullah (1999) mendapatkan hasil bahwa variabilitas persediaan metode rata-rata dengan metode FIFO tidak berbeda secara singnifikan.

\section{d. Intensitas Persediaan}

Intensitas persediaan (ratio perputaran persediaan) mengindikasikan velositas persediaan, selain itu intensitas juga menunjukkan sifat bisnis perusahaan (Lee dan Hsieh, 1985). Anthony et al, (2000) menyatakan bahwa perputaran persediaan dan hari perputaran persediaan dipengaruhi oleh metode persediaan. Karena metode LIFO menghasilkan nilai persediaan akhir pada neraca yang lebih rendah dibandingkan jika perusahaan menggunakan metode FIFO.

Penelitian yang dilakukan oleh Mukhlasin mendapat bahwa intensitas pesediaan mempengaruhi secara singnifikan terhadap pemilihan metode akuntansi persediaan. Hasil penelitian ini mendukung penelitian Lindahl (1989) yang juga mendapatkan hasil yang singnifikan untuk intensitas persediaan pada pemilihan metode akuntansi persediaan. 


\section{e. Intensitas Modal}

Lee dan Hsieh (1985) mengemukakan bahwa intensitas modal menunjukkan kondisi perusahaan yang mempunyai proporsi lebih tinggi untuk biaya tetap pada biaya variabel dalam meningkatkan arti penting keuangaan dan perencanaan produksi, yang berarti bahwa cost of capital lebih besar. Perusahaan dengan metode LIFO lebih terkendali dan lebih terencana dibanding FIFO. Metode LIFO memiliki cost of capital lebih rendah sehingga intensitas modal perusahaan akan mempunyai keunggulan komparatif ketika perusahaan tersebut mengadopsi metode LIFO.

Memilih metode akuntansi persediaan dari sudut pandang political cost dan tax hioptesis sangat konsisten, karena political cost menginginkaam earning perusahaan yang rendah sedangkan tax hipotesis menghendaki value perusahaan dengan meminimalkan biaya pajak. Metode FIFO menghasilkan earning yang lebih besar dan biaya pajak yang lebih besar dibandingkan dengan metode rat-rata, maka metode yang lebih disukai adalah metode rata-rata.

Penelitian yang dilakukan oleh Mukhlasin (2001) tidak memberikan hasil yang singnifikan terhadap pemilihan metode akuntansi persediaan. Sedangkan Dopuch dan Pincus (1988) membuktikan bahwaintensitas modal antaraperusahaan yang mengadopsi metode LIFO dengan perusahaan yang menggunakan metode FIFO berbeda secara singnifikan.।

Sesuai uraian sebelummnya, maka diajukan model penelitian sebagai berikut:

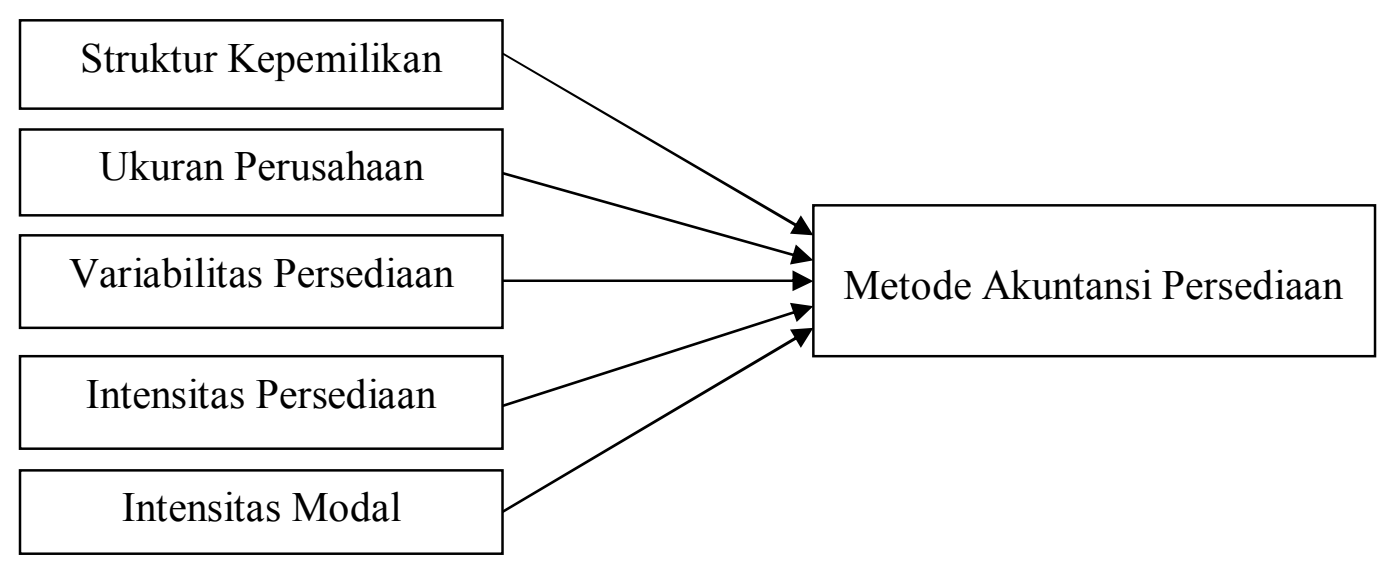

Gambar 1. Model penelitian 
Berdasarkan telaah teori dan pemgembangan hipotesis tersebut maka dirumuskan hipotesis sebagai berikut:

H1 : Struktur kepemilikan berpengaruh terhadap pemilihan metode akuntansi persediaan.

H2 : Ukuran perusahaan berpengaruh terhadap pemilihan metode akuntansi persediaan.

H3 : Variabilitas persediaan berpengaruh terhadap pemilihan metode akuntansi persediaan.

H4 : Intensitas persediaan berpengaruh terhadap pemilihan metode akuntansi persediaan.

H5 : Intensitas modal berpengaruh terhadap pemilihan metode akuntansi persediaan.

\section{METODE PENELITIAN}

\section{Populasi dan Sampel}

Populasi dari penelitian ini adalah perusahaan Food and beveragr yang terdaftar di Bursa Efek Indonesia (BEI). Prosedur pemilihan sampel menggunakan metode purposive sampling

\section{Operasionalisasi Variabel}

Struktur kepemilikan, dilihat dari kepemilikan saham oleh manejer pada suatu perusahaan. Pengukuran variabel dummy, 1 jika manajer memiliki saham pada perusahaan dan 0 jika manejer tidak memiliki saham pada perusahaan tersebut. Sampel yang diambil adalah perusahaan yang sahamnya dimiliki secara terus menerus oleh manajer selama periode pengamatan.

Ukuran perusahaan, pengukuran variabel ini diambil dari penelitian Morse dan Richardson (1983). Variabel diukur dengan total penjualan bersih selama 4 tahun dibagi dengan empat.

$$
\mathbf{U P}=\frac{\text { Net Sales }}{4}
$$

Variabilitas persediaan, diukur dari koefisien variasi persediaan akhir selama 4 tahun. Koefisien variasi diperoleh dengan membagi standar deviasi persediaan dengan rata-rata persediaan. Pengukuran variabel ini berdasarkan penelitian dari Dopuch dan Pincus (1988). Standar deviasi dihitung dari standar deviasi persediaan selama 4 tahun. Rata-rata persediaan dihitung dari totalpersediaan selama 4 tahun dibagi 4. 


$$
\mathrm{VP}=\frac{\text { Standar Deviasi Inventory }}{\text { Average inventory }}
$$

Intensitas Persediaan, diukur dengan rata-rata ratio persediaan pada penjualan bersih. Persediaan adalah persediaan akhir perusahaan yang tercantum pada neraca tahunan. Penjualan bersih adalah nilai penjualan bersih perusahaan yang tercantum pada laporan laba rugi tahunan. Sedangkan rata-rata rasio persediaan pada penjualan bersih diperoleh dari jumlah persediaan dibagi dengan net sales dari tahun 2006 sampai dengan tahun 2009 dibagi dengan periode penelitian (4 tahun).

Intensitas Modal, untuk mengukur intensitas modal digunakan ratarata net capital intencity. Net capital intencity didapat dari aktiva tetap bersih (net fixed asset) dibagi dengan penjualan. Sedangkan rata-rata net capital intensity dihasilkan dari jumlah net capital intencity dari tahun 2006-2009 dibagi 4 tahun.

$$
\mathrm{IM}=\frac{\text { net capital intencity }}{\text { net fixed asset }}
$$

\section{Tehnik Analisis Data}

Untuk menguji hipotsis dilakukan 2 tahap pengujian, yaitu univariate test dan multivariate test. Univariate test dilakukan untuk mengetahui perbedaan variabel independent terhadap variabel dependent. Pengujian variabel dilihat dari distribusi datanya. Normalitas data diketahui dengan melakukan one sample-Kolmogorov-Smirnov test. Apabila nilai Asymptotic Singnifikance dari data lebih besar dari 5\% maka distribusi datanya normal. Tetapi jika nilai singnifikasinya lebih kecil dari 5\% maka distribusi datanya tidak normal. Apabila datanya normal maka akan di uji dengan uji-t. Sedangkan untuk data yang tidak normal maka akan diuji dengan Mann-whitney.

Pengujian Multivariate test adalah untuk mengetahui pengaruh variabel independent terhadap variabel dependent. Pengujian multivariate dilakukan melalui 2 tahap, pertama menguji keseluruhan variabel selama periode pengamatan (4 tahun), dan yang kedua pengujian seluruh variabel untuk masing-masing tahun pengamatan. Hal ini untuk mengetahui apakah ada pengaruh dari perbedaan tingkat inflasi dari masing-masing tahun pengamatan. Pengujian hipotesis akan menggunakan regresi logit (logistic regression). 


\section{HASIL PENELITIAN DAN PEMBAHASAN}

Populasi penelitian terdiri dari perusahaan Manufaktur yang listing di Bursa Efek Indonesia. Berdasarkan kriteria pemilihan sampel, yaitu purposive sampling maka sampel penelitian diperoleh 44 perusahaan manufacturing yang terdaftar di Bursa Efek Indonesia (BEI) seperti tampak dalam table 1.

\section{Tabel 1}

Data Hasil Penelitian

\begin{tabular}{|c|c|c|c|c|c|c|}
\hline Perusahaan & Struktur & Ukuran & Variabilitas & Intensitas & Intensitas & Metode \\
\hline & Pemilikan & Perusahaan & Persediaan & Persediaan & Modal & Persediaan \\
\hline AKPI & 1 & $883,294,818,828$ & 0.327 & 0.082 & 0.672 & FIFO \\
\hline ARNA & 1 & $4,180,264,467,345$ & 0.631 & 0.158 & 0.938 & FIFO \\
\hline BTON & 1 & $64,652,876,895,000$ & 0.256 & 0.064 & 0.752 & FIFO \\
\hline CLPI & 1 & $378,374,330,031$ & 0.200 & 0.050 & 0.851 & FIFO \\
\hline CTBN & 1 & $22,167,126,935,443$ & 0.492 & 0.123 & 0.754 & FIFO \\
\hline FASW & 1 & $2,541,170,136,581$ & 0.277 & 0.069 & 0.824 & FIFO \\
\hline IGAR & 1 & $3,359,324,162,500$ & 0.167 & 0.042 & 0.858 & FIFO \\
\hline INTP & 1 & $2,241,620,525,484$ & 0.608 & 0.152 & 0.825 & FIFO \\
\hline JPRS & 1 & $834,370,655,000$ & 0.108 & 0.027 & 0.738 & FIFO \\
\hline LION & 1 & $3,778,231,531,870$ & 0.287 & 0.072 & 0.935 & FIFO \\
\hline LMSH & 0 & $6,890,555,512,079$ & 0.385 & 0.096 & 0.801 & FIFO \\
\hline SIMA & 0 & $1,246,068,832,993$ & 0.131 & 0.033 & 0.744 & $\begin{array}{c}\text { Metode } \\
\text { Rata-rata }\end{array}$ \\
\hline SMGR & 1 & $378,647,870,000$ & 0.237 & 0.059 & 0.815 & $\begin{array}{c}\text { Metode } \\
\text { Rata-rata }\end{array}$ \\
\hline SOBI & 1 & $1,236,983,000,352$ & 0.063 & 0.016 & 0.912 & $\begin{array}{c}\text { Metode } \\
\text { Rata-rata }\end{array}$ \\
\hline SRSN & 1 & $275,387,207,500$ & 0.063 & 0.016 & 0.311 & $\begin{array}{c}\text { Metode } \\
\text { Rata-rata }\end{array}$ \\
\hline TIRT & 0 & $2,475,152,897,500$ & 0.284 & 0.071 & 0.536 & $\begin{array}{c}\text { Metode } \\
\text { Rata-rata }\end{array}$ \\
\hline TOTO & 0 & $4,377,636,717,343$ & 0.478 & 0.120 & 0.584 & $\begin{array}{c}\text { Metode } \\
\text { Rata-rata }\end{array}$ \\
\hline UNIC & 0 & $880,287,306,919$ & 0.325 & 0.081 & 0.238 & $\begin{array}{c}\text { Metode } \\
\text { Rata-rata }\end{array}$ \\
\hline$\overline{A S I I}$ & 0 & $4,179,733,615,069$ & 0.631 & 0.158 & 0.289 & $\begin{array}{c}\text { Metode } \\
\text { Rata-rata }\end{array}$ \\
\hline AUTO & 0 & $64,441,735,137,500$ & 0.253 & 0.063 & 0.263 & $\begin{array}{c}\text { Metode } \\
\text { Rata-rata }\end{array}$ \\
\hline BATA & 0 & $377,120,980,348$ & 0.193 & 0.048 & 0.179 & $\begin{array}{c}\text { Metode } \\
\text { Rata-rata }\end{array}$ \\
\hline DOID & 0 & $22,084,014,299,910$ & 0.492 & 0.123 & 0.307 & FIFO \\
\hline GJTL & 0 & $2,531,014,343,097$ & 0.269 & 0.067 & 0.251 & FIFO \\
\hline INDR & 0 & $3,347,742,250,000$ & 0.158 & 0.039 & 0.258 & FIFO \\
\hline PBRX & 0 & $2,235,462,676,350$ & 0.613 & 0.153 & 0.369 & FIFO \\
\hline RDTX & 0 & $831,667,575,000$ & 0.098 & 0.024 & 0.204 & FIFO \\
\hline
\end{tabular}




\begin{tabular}{|c|c|c|c|c|c|c|}
\hline $\mathrm{RICY}$ & 0 & $3,763,314,282,225$ & 0.280 & 0.070 & 0.606 & FIFO \\
\hline AQUA & 0 & $6,859,711,246,795$ & 0.378 & 0.095 & 0.627 & $\begin{array}{c}\text { Metode } \\
\text { Rata-rata }\end{array}$ \\
\hline DAVO & 0 & $1,243,007,874,897$ & 0.132 & 0.033 & 0.691 & $\begin{array}{c}\text { Metode } \\
\text { Rata-rata }\end{array}$ \\
\hline DLTA & 0 & $377,207,175,000$ & 0.229 & 0.057 & 0.563 & $\begin{array}{c}\text { Metode } \\
\text { Rata-rata }\end{array}$ \\
\hline DVLA & 0 & $1,233,615,031,261$ & 0.055 & 0.014 & 0.617 & $\begin{array}{c}\text { Metode } \\
\text { Rata-rata }\end{array}$ \\
\hline MYOR & 0 & $275,644,222,500$ & 0.057 & 0.014 & 0.693 & $\begin{array}{c}\text { Metode } \\
\text { Rata-rata }\end{array}$ \\
\hline HMSP & 0 & $2,465,907,075,000$ & 0.277 & 0.069 & 0.816 & FIFO \\
\hline INDF & 0 & $4,355,190,741,993$ & 0.470 & 0.118 & 0.616 & FIFO \\
\hline KAEF & 0 & $371,602,136,733$ & 0.193 & 0.048 & 0.696 & $\begin{array}{c}\text { Metode } \\
\text { Rata-rata }\end{array}$ \\
\hline KLBF & 0 & $21,760,833,602,838$ & 0.492 & 0.123 & 0.859 & $\begin{array}{c}\text { Metode } \\
\text { Rata-rata }\end{array}$ \\
\hline MERK & 0 & $2,493,975,108,807$ & 0.269 & 0.067 & 0.887 & $\begin{array}{c}\text { Metode } \\
\text { Rata-rata }\end{array}$ \\
\hline MLBI & 0 & $3,298,750,900,000$ & 0.158 & 0.039 & 0.862 & FIFO \\
\hline MRAT & 0 & $2,202,748,588,403$ & 0.613 & 0.153 & 0.869 & $\begin{array}{c}\text { Metode } \\
\text { Rata-rata }\end{array}$ \\
\hline GGRM & 0 & $819,496,830,000$ & 0.098 & 0.024 & 0.797 & $\begin{array}{c}\text { Metode } \\
\text { Rata-rata }\end{array}$ \\
\hline PYFA & 0 & $3,708,241,390,290$ & 0.280 & 0.070 & 0.922 & $\begin{array}{c}\text { Metode } \\
\text { Rata-rata }\end{array}$ \\
\hline RMBA & 0 & $6,759,325,228,549$ & 0.378 & 0.095 & 0.734 & $\begin{array}{c}\text { Metode } \\
\text { Rata-rata }\end{array}$ \\
\hline PYFA & 0 & $1,224,817,515,753$ & 0.132 & 0.033 & 0.882 & $\begin{array}{c}\text { Metode } \\
\text { Rata-rata }\end{array}$ \\
\hline RMBA & 0 & $371,687,070,000$ & 0.229 & 0.057 & 0.835 & $\begin{array}{c}\text { Metode } \\
\text { Rata-rata }\end{array}$ \\
\hline
\end{tabular}

Sumber : BEI, 2010.

\section{Analisis Pengaruh dengan Regresi Logistik}

\section{a. Hasil Uji Pengaruh Secara Simultan}

Setelah data dianalisis dengan menggunakan regresi logistic secara simultan diperoleh hasil pengujian seperti tampak dalam tabel 2 .

Tabel 2

\section{Hasil Uji Pengaruh Simultan}

Omnibus Tests of Model Coefficients

\begin{tabular}{|ll|r|r|r|}
\hline & & Chi-square & \multicolumn{1}{c|}{ df } & \multicolumn{1}{c|}{ Sig. } \\
\hline Step 1 & Step & 19.315 & 5 & .002 \\
& Block & 19.315 & 5 & .002 \\
& Model & 19.315 & 5 & .002 \\
\hline
\end{tabular}

Sumber: Data Sekunder diolah, 2010

Dari tabel di atas terlihat bahwa nilai sig- $\mathrm{p}=0.02$, lebih kecil dari sig$\alpha(0.05)$, hal ini berarti pengujian secara serempak (simultan) kelima variable bebas (struktur pemilikan, ukuran perusahaan, variabilitas 
persediaan, intensitas persediaan, dan intensitas modal memiliki pengaruh yang signifikan terhadap variable terikat (metode akuntansi persediaan)

\section{b. Hasil Uji Pengaruh Secara Parsial}

Hasil uji pengaruh logistik secara parsial antara setiap variabel struktur kepemilikan (X1), ukuran perusahaan (X2), variabilitas persediaan (X3), intensitas persediaan (X4), dan intensitas modal (X5) terhadap metode akuntansi persediaan (Y) dapat dilihat melalui Tabel 3.

\section{Tabel 3}

\section{Hasil Uji Pengaruh Parsial}

Variables in the Equation

\begin{tabular}{|ll|r|r|r|r|r|r|}
\hline & \multicolumn{1}{|c|}{ B } & \multicolumn{1}{|c|}{ S.E. } & \multicolumn{1}{c|}{ Wald } & df & \multicolumn{1}{c|}{ Sig. } & \multicolumn{1}{c|}{ Exp(B) } \\
\hline Step & Struktur & 3.517 & 1.193 & 8.696 & 1 & .003 & 33.671 \\
& Ukuran & .726 & .414 & 3.072 & 1 & .080 & 2.067 \\
& Variabilitas & 852.431 & 424.881 & 4.025 & 1 & .045 &. \\
& IntensitasPersediaan & -3399.342 & 1696.626 & 4.014 & 1 & .045 & .000 \\
& IntensitasModal & -1.416 & 1.608 & .776 & 1 & .378 & .243 \\
& Constant & -21.831 & 11.444 & 3.639 & 1 & .056 & .000 \\
\hline
\end{tabular}

a. Variable(s) entered on step 1: Struktur, Ukuran, Variabilitas, IntensitasPersediaan, IntensitasModa

Sumber: Data Sekunder diolah, 2010

Dari tabel di atas terlihat bahwa ada 3 variabel bebas (struktur pemilikan, variabilitas persediaan, dan intensitas persediaan) yang memiliki nilai koefisien signifikansi lebih kecil dari sig- $\alpha$ (0.05), hal ini berarti ketiga variabel ini berpengaruh signifikan terhadap variabel terikat (pemilihan metode akuntansi persediaan), sedangkan kedua variabel bebas lainnya (ukuran perusahaan dan intensitas modal memiliki nilai koefisien lebih besar dari sig- $\alpha$ (0.05), hal ini berarti kedua variabel bebas ini tidak berpengaruh signifikan terhadap variabel terikat (pemilihan metode akuntansi persediaan) jika pengujian dilakukan secara sendiri sendiri (parsial).

Dengan demikian dapat disimpulkan bahwa jika pengujian dilakukan secara serentak (simultan), kelima variabel bebas ((struktur pemilikan, ukuran perusahaan, variabilitas persediaan, intensitas persediaan, dan intensitas modal memiliki pengaruh secara signifikan terhadap variable terikat (metode akuntansi persediaan), dan jika pengujian dilakukan secara sendiri sendiri (parsial), maka hanya 3 dari 5 variabel bebas (yakni 
struktur pemilikan, variabilitas persediaan dan intensitas persediaan) yang berpengaruh signifikan terhadap variabel terikat ( pemilihan metode akuntansi persediaan).

\section{c. Uji Determinasi $R$}

Untuk mengetahui besarnya pengaruh serentak kelima variabel bebas (struktur kepemilikan (X1), ukuran perusahaan (X2), variabilitas persediaan (X3), intensitas persediaan (X4), dan intensitas modal (X5) terhadap metode akuntansi persediaan (Y) dapat dilihat pada table 4.

\section{Tabel 4}

\section{Hasil Uji Determinasi R}

\section{Model Summary}

\begin{tabular}{|l|c|c|c|}
\hline Step & $\begin{array}{c}-2 \text { Log } \\
\text { likelihood }\end{array}$ & $\begin{array}{c}\text { Cox \& Snell } \\
\text { R Square }\end{array}$ & $\begin{array}{c}\text { Nagelkerke } \\
\text { R Square }\end{array}$ \\
\hline 1 & $41.318^{\mathrm{a}}$ & .355 & .475 \\
\hline
\end{tabular}

a. Estimation terminated at iteration number 6 because parameter estimates changed by less than .001 .

Sumber: Data Sekunder diolah, 2010

Dari tabel di atas terlihat bahwa nilai R-square Negelkerke $=0.475$, sehingga besarnya pengaruh logistik kelima variabel bebas (struktur kepemilikan (X1), ukuran perusahaan (X2), variabilitas persediaan (X3), intensitas persediaan (X4), dan intensitas modal (X5) terhadap metode akuntansi persediaan (Y) dapat dikalkulasikan sebagai berikut :

$$
\mathrm{K}=\mathrm{R} \text {-square } \mathrm{X} 100 \%=0.475 \times 100 \%=47.5 \% \text {. }
$$

Dengan demikian besarnya pengaruh serempak kelima variabel bebas terhadap variabel terikat dalam penelitian ini adalah sebesar $47.5 \%$.

\section{d. Persamaan Regresi Logistik}

Persamaan regresi logistik dapat disusun berdasarkan nilai koefisien masing masing variabel dapat dilihat pada table 5 . 
Tabel 5

Hasil Perhitungan Koefisien Model Regresi Logistik Binary

\begin{tabular}{|ll|r|r|r|r|r|r|}
\hline \multicolumn{1}{|c|}{ Variables in the Equation } \\
\hline Step & Struktur & \multicolumn{1}{|c|}{ B } & \multicolumn{1}{|c|}{ S.E. } & Wald & df & \multicolumn{1}{c|}{ Sig. } & Exp(B) \\
\hline 1 & Ukuran & 3.517 & 1.193 & 8.696 & 1 & .003 & 33.671 \\
& Variabilitas & .726 & .414 & 3.072 & 1 & .080 & 2.067 \\
& IntensitasPersediaan & 852.431 & 424.881 & 4.025 & 1 & .045 &. \\
& IntensitasModal & -3399.342 & 1696.626 & 4.014 & 1 & .045 & .000 \\
& Constant & -1.416 & 1.608 & .776 & 1 & .378 & .243 \\
& -21.831 & 11.444 & 3.639 & 1 & .056 & .000 \\
\hline
\end{tabular}

a. Variable(s) entered on step 1: Struktur, Ukuran, Variabilitas, IntensitasPersediaan, IntensitasModal

Sumber: Data Sekunder diolah, 2010

Berdasarkan nilai koefisien masing masing variabel tersebut di atas, maka persamaan regresi logistik dalam penelitian ini dapat disusun sebagai berikut :

$\ln \left(\frac{\pi}{1-\pi}\right)=\exp (-21.831)+3.517 X_{1}+0.726 X_{2}+652.431 X_{3}-3399.342 X_{4}-1.416 X_{5}$

\section{Uji-Beda}

Uji beda dilakukan untuk memperoleh bukti empiris bahwa metode akuntasi persediaan FIFO berbeda dengan metode rata-rata dilihat dari struktur kepemilikan (X1), ukuran perusahaan (X2), variabilitas persediaan (X3), intensitas persediaan (X4), dan intensitas modal (X5)

\section{a. Struktur Kepemilikan}

Uji beda dilakukan untuk mengetahui apakah ada perbedaan metode akuntasi persediaan FIFO dan metode rata-rata dilihat dari struktur kepemilikan dengan menggunakan Independent-Sampel T-Test (Uji-T) dengan hasil seperti tabel 6 .

Tabel 6

Hasil Uji Beda Metode Akuntansi Persediaan Berdasarkan Struktur Kepemilikan

Group Statistics

\begin{tabular}{|ll|r|r|r|c|}
\hline & Metode Akuntansi & & & Std. Error \\
& Persediaan & N & Mean & Std. Deviation & \begin{tabular}{c} 
Mean \\
\hline Struktur Pemilikan
\end{tabular} FIFO \\
& Metode rata-rata & 20 & .50 & .513 & .115 \\
& 24 & .13 & .338 & .069 \\
\hline
\end{tabular}

Sumber: Data Sekunder diolah, 2010 
Dari tabel 6 terlihat bahwa nilai mean (mean) metode FIFO sebesar 0.50 dan nilai mean metode rata-rata sebesar 0.13 . Dengan kata lain, ada perbedaan metode akuntansi persediaan FIFO dengan metode rata-rata dilihat dari struktur kepemilikan. Selanjutnya untuk mengetahui apakah perbedaan tersebut signifikan atau tidak, dilakukan uji Levene's test dengan hasil seperti tabel 7.

Tabel 7

Hasil Uji Signifikansi

\begin{tabular}{|c|c|c|c|c|c|c|c|c|}
\hline \multicolumn{9}{|c|}{ Independent Samples Test } \\
\hline & \multicolumn{2}{|c|}{$\begin{array}{l}\text { Levene's Test for } \\
\text { Equality of } \\
\text { Variances }\end{array}$} & \multicolumn{6}{|c|}{ t-test for Equality of Means } \\
\hline & \multirow[b]{2}{*}{$\mathrm{F}$} & \multirow[b]{2}{*}{ Sig. } & \multirow[b]{2}{*}{$\mathrm{t}$} & \multirow[b]{2}{*}{$d f$} & \multirow{2}{*}{$\begin{array}{c}\text { Sig. } \\
\text { (2-tailed) }\end{array}$} & \multirow{2}{*}{$\begin{array}{c}\text { Mean } \\
\text { Difference }\end{array}$} & \multicolumn{2}{|c|}{$\begin{array}{l}95 \% \text { Confidence } \\
\text { Interval of the } \\
\text { Difference }\end{array}$} \\
\hline & & & & & & & Lower & Upper \\
\hline Struktur Pemilikan & 24.545 & .000 & 2.907 & 42 & .006 & .375 & .115 & .635 \\
\hline & & & 2.802 & 31.8 & .009 & .375 & .102 & .648 \\
\hline
\end{tabular}

Sumber: Data Sekunder diolah, 2010

Dari tabel 7 terlihat bahwa ada perbedaan mean (mean difference) sebesar 0.375 antara metode FIFO dan metode Rata-rata, dan karena nilai $\operatorname{sig}(2$-tailed $)=0.006$ lebih kecil dari sig- $\alpha(0.05)$, maka dapat disimpulkan bahwa ada perbedaan signifikan antara metode akuntansi persediaan FIFO dan metode rata-rata ditinjau dari struktur kepemilikan perusahaan.

\section{b. Ukuran perusahaan}

Uji beda perbedaan metode akuntasi persediaan FIFO dan metode ratarata dilihat dari ukuran perusahaan memberikan hasil seperti tabel 8

Tabel 8

Hasil Uji Beda Metode Akuntansi Persediaan Berdasarkan Ukuran Perusahaan

Group Statistics

\begin{tabular}{|ll|r|r|r|c|}
\hline & Metode Akuntansi & & & & Std. Error \\
& Persediaan & N & Mean & Std. Deviation & \multicolumn{1}{c|}{ Mean } \\
\hline Ukuran Perusahaan & FIFO & 20 & 29.1852 & 1.74893 & .39107 \\
& Metode rata-rata & 24 & 28.0963 & 1.40888 & .28759 \\
\hline
\end{tabular}

Sumber: Data Sekunder diolah, 2010 
Dari tabel 8 terlihat bahwa nilai mean (mean) metode FIFO sebesar 29.1852 dan nilai mean metode rata-rata sebesar 28.0963. Dengan kata lain, ada perbedaan metode akuntansi persediaan FIFO dengan metode rata-rata dilihat dari ukuran perusahaan. Selanjutnya untuk mengetahui apakah perbedaan tersebut signifikan atau tidak, dilakukan uji Levene's test dengan hasil seperti tabel 9.

Tabel 9.

Hasil Uji Signifikansi

\begin{tabular}{|c|c|c|c|c|c|c|c|c|}
\hline \multicolumn{9}{|c|}{ Independent Samples Test } \\
\hline & \multicolumn{2}{|c|}{$\begin{array}{c}\text { Levene's Test for } \\
\text { Equality of } \\
\text { Variances } \\
\end{array}$} & \multicolumn{6}{|c|}{ t-test for Equality of Means } \\
\hline & \multirow[b]{2}{*}{$\mathrm{F}$} & \multirow[b]{2}{*}{ Sig. } & \multirow[b]{2}{*}{$t$} & \multirow[b]{2}{*}{ df } & \multirow{2}{*}{$\begin{array}{c}\text { Sig. } \\
\text { (2-tailed) }\end{array}$} & \multirow{2}{*}{$\begin{array}{c}\text { Mean } \\
\text { Difference }\end{array}$} & \multicolumn{2}{|c|}{$\begin{array}{l}95 \% \text { Confidence } \\
\text { Interval of the } \\
\text { Difference }\end{array}$} \\
\hline & & & & & & & Lower & Upper \\
\hline \multirow[t]{2}{*}{ Ukuran Perusahaan } & .126 & .724 & 2.288 & 42 & .027 & 1.08890 & .12849 & 2.04931 \\
\hline & & & 2.243 & 36.33 & .031 & 1.08890 & .10471 & 2.07309 \\
\hline
\end{tabular}

Sumber: Data Sekunder diolah, 2010

Dari tabel 9 terlihat bahwa ada perbedaan mean (mean difference) sebesar 0.108 antara metode FIFO dan metode rata-rata, dan karena nilai sig $(2$-tailed $)=0.027$ lebih kecil dari sig- $\alpha(0.05)$, maka dapat disimpulkan bahwa ada perbedaan signifikan antara metode akuntansi persediaan FIFO dan metode rata-rata ditinjau dari ukuran perusahaan.

\section{c. Variabilitas persediaan}

Uji beda perbedaan metode akuntasi persediaan FIFO dan metode ratarata dilihat dari variabilitas persediaan memberikan hasil seperti tampak pada tabel 10 .

Tabel 10.

Hasil Uji Beda Metode Akuntansi Persediaan Berdasarkan Variabilitas Persediaan

\section{Group Statistics}

\begin{tabular}{|l|r|r|r|c|}
\hline $\begin{array}{l}\text { Metode Akuntans } \\
\text { Persediaan }\end{array}$ & $\mathrm{N}$ & Mean & Std. Deviation & $\begin{array}{c}\text { Std. Error } \\
\text { Mean }\end{array}$ \\
\hline Variabilitas Persediaar FIFO & 20 & .3277 & .16981 & .03797 \\
Metode rata-rata & 24 & .2580 & .16741 & .03417 \\
\hline
\end{tabular}

Sumber: Data Sekunder diolah, 2010 
Dari tabel 10 terlihat bahwa nilai mean (mean) metode FIFO sebesar 0.3277 dan nilai mean metode rata-rata sebesar 0.2580 . Dengan kata lain, tidak ada perbedaan metode akuntansi persediaan FIFO dengan metode rata-rata dilihat dari variabilitas persediaan, oleh karena itu tidak dilanjutkan dengan uji Levene's test

\section{d. Intensitas persediaan}

Uji beda perbedaan metode akuntasi persediaan FIFO dan metode ratarata dilihat dari intensitas persediaan memberikan hasil seperti tampak pada tabel 11.

Tabel 11.

Hasil Uji Beda Metode Akuntansi Persediaan Berdasarkan Intensitas persediaan

\begin{tabular}{|c|c|c|c|c|c|}
\hline \multicolumn{6}{|c|}{ Group Statistics } \\
\hline & $\begin{array}{l}\text { Metode Akuntansi } \\
\text { Persediaan }\end{array}$ & $\mathrm{N}$ & Mean & Std. Deviation & $\begin{array}{l}\text { Std. Error } \\
\text { Mean }\end{array}$ \\
\hline \multirow[t]{2}{*}{ Intensitas Persediaan } & FIFO & 20 & .0819 & .04256 & .00952 \\
\hline & Metode rata-rata & 24 & .0645 & .04191 & .00856 \\
\hline
\end{tabular}

Sumber: Data Sekunder diolah, 2010

Dari tabel 11 terlihat bahwa nilai mean (mean) metode FIFO sebesar 0.0819 dan nilai mean metode rata-rata sebesar 0.0645 . Dengan kata lain ada perbedaan metode akuntansi persediaan FIFO dengan metode rata-rata dilihat dari intensitas persediaan. Selanjutnya untuk mengetahui apakah perbedaan tersebut signifikan atau tidak, dilakukan uji Levene's test dengan hasil seperti tabel 12 .

Tabel 12.

Hasil Uji Signifikansi

Independent Samples Test

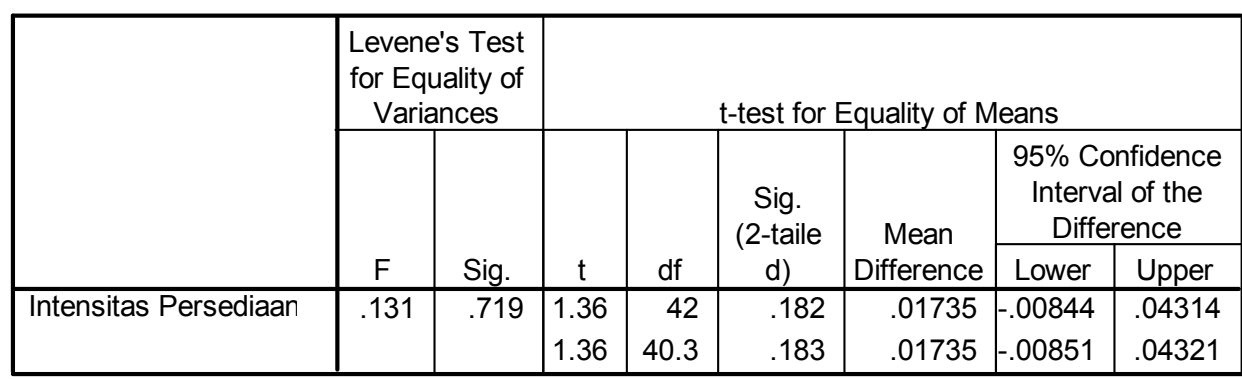

Sumber: Data Sekunder diolah, 2010 
Dari tabel 12 terlihat bahwa ada perbedaan mean (mean difference) sebesar 0.1735 antara metode FIFO dan metode Rata-rata, tetapi karena nilai sig $(2$-tailed) $=0.182$ lebih besar dari sig- $\alpha$ (0.05), maka dapat disimpulkan bahwa tidak ada perbedaan signifikan antara metode akuntansi persediaan FIFO dan metode rata-rata ditinjau dari intensitas persediaan.

\section{e. Intensitas modal}

Uji beda perbedaan metode akuntasi modal FIFO dan metode rata-rata dilihat dari intensitas modal memberikan hasil seperti tampak pada tabel 13 .

Tabel 13.

Hasil Uji Beda Metode Akuntansi Modal Berdasarkan Intensitas Modal

Group Statistics

\begin{tabular}{|c|c|c|c|c|c|}
\hline & $\begin{array}{l}\text { Metode Akuntansi } \\
\text { Persediaan }\end{array}$ & $\mathrm{N}$ & Mean & Std. Deviation & $\begin{array}{l}\text { Std. Error } \\
\text { Mean }\end{array}$ \\
\hline \multirow[t]{2}{*}{ Intensitas Modal } & FIFO & 20 & .6619 & .24518 & .05482 \\
\hline & Metode rata-rata & 24 & .6476 & .23423 & .04781 \\
\hline
\end{tabular}

Sumber: Data Sekunder diolah, 2010

Dari table 13 terlihat bahwa nilai mean (mean) metode FIFO sebesar 0.6619 dan nilai mean metode rata-rata sebesar 0.6476. Dengan kata lain, ada perbedaan metode akuntansi modal FIFO dengan metode rata-rata dilihat dari intensitas modal. Selanjutnya untuk mengetahui apakah perbedaan tersebut signifikan atau tidak, dilakukan uji Levene's test seperti yang ditampilkan dalam tabel 14.

Tabel 14.

\section{Hasil Uji Signifikansi}

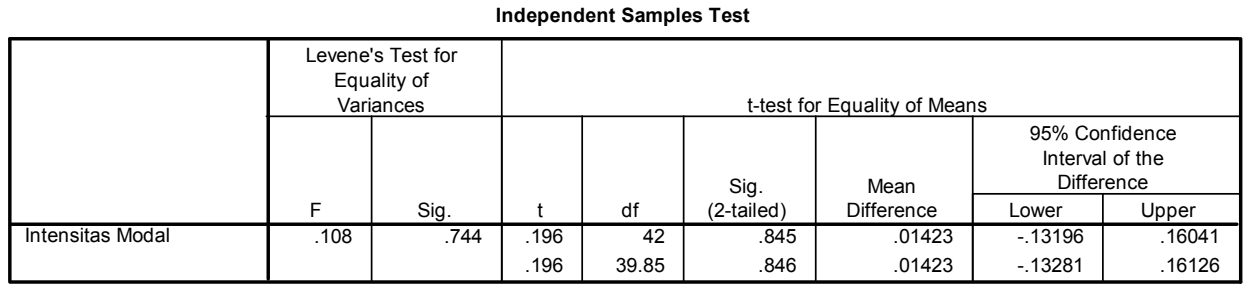

Sumber: Data Sekunder diolah, 2010 
Dari tabel 14 terlihat bahwa ada perbedaan mean (mean difference) sebesar 0.1423 antara metode FIFO dan metode Rata-rata tetapi karena nilai sig-(2-tailed) sebesar 0.845 lebih besar dari sig- $\alpha$ (0.05), maka dapat disimpulkan bahwa tidak perbedaan metode akuntansi modal FIFO dan metode rata-rata tidak signifikan dilihat dari struktur intensitas modal.

\section{Pembahasan}

Hasil penelitian ini sama dengan hasil penelitian sebelumnya oleh Niehaus (1989) dimana ada hubungan signifikan antara struktur pemilikan dengan pemilihan metode akuntansi. Semakin besar kepemilikan manajer maka konflik yang terjadi semakin kecil. Menurut Niehaus (1889), jika persentase kepemilikan diluar kepemilikan manajer kecil, maka kepentingan untuk memonitor manajer perusahaan juga semakin kecil karena biaya monitoring lebih besar dari manfaat yang diterima.

Hasil penelitian ini berbeda dengan penelitian Salma (2001) bahwa tinggi rendahnya persentase pemilikan saham oleh manajer tidak mempengaruhi pemilihan metode akuntansi persediaan.

Dari hasil pengujian membuktikan bahwa baik perusahaan besar maupun perusahaan kecik selalu ingin memaksimalkan nilai perusahaannya dengan kata lain perusahaan besar maupun kecil lebih memilih untuk memaksimalkan laba. Sehingga tidak mempengaruhi pemilihan metode penilaiaan persediaan.

Hasil penelitian ini sesuai dengan hasil penelitian Salma (2001) dimana dibuktikan bahwa ukuran perusahaan memiliki pengaruh signifikan terhadap pemilihan metode akuntansi persediaan.

Hasil penelitian ini sesuai dengan dengan hasil penelitian sebelumnya oleh Salma (2001) bahwa variabilitas persediaan mempunyai pengaruh signifikan terhadap pemilihan metode akuntansi persediaan. Tetapi hasil penelitian ini berbeda dengan penelitian sebelumnya oleh Mukhlasin (2001) bahwa tidak ada pengaruh signifikan dari variabilitas persediaan terhadap pemilihan metode akuntansi. Hal yang sama dikemukakan oleh Abdullah (1999) bahwa metode dan metode rata-rata tidak memiliki perbedaan signifikan ditinjau dari variabilitas persediaan.

Hasil uji beda memperlihatkan bahwa tidak ada perbedaan signifikan antara metode akuntansi persediaan FIFO dengan metode rata-rata dilihat dari intensitas persediaan. Tetapi, hasil analisis regresi logistic menunjukkan bahwa variabilitas persediaan berpengaruh signifikan terhadap metode akuntansi persediaan. Hal ini diindikasikan oleh nilai sig-p $=0.045$, lebih kecil dari sig- $\alpha(0.05)$. 
Hasil penelitian ini sesuai dengan hasil penelitian sebelumnya oleh Mukhlasin bahwa intensitas persediaan mempengaruhi secara signifikan pemilihan metode akuntansi persediaan. Hal yang sama juga dibuktikan oleh Lindahl (1989) bahwa intensitas persediaan berpengaruh signifikan terhadap metode akuntansi persediaan.

Hasil penelitian ini sesuai dengan hasil penelitian Mukhlasin (2001) bahwa tidak ada pengaruh signifikan dari intensitas modal terhadap pemilihan metode akutnansi persediaan. Tetapi hasil penelitian ini berbeda dengan hasil penelitian sebelumnya oleh Dopuch dan Pincus (1988) bahwa ada perbedaan signifikan antara metode FIFO dengan metode rata rata dilihat dari intensitas modalnya.

Menurut Cushing dan LeClere (1992), pemilihan metode akuntansi untuk persediaan merupakan suatu keputusan yang memerlukan banyak pertimbangan. Manajemen cenderung untuk memilih metode yang menguntungkan perusahaan. Salah satu alasannya adalah untuk memenuhi keinginan para investor dalam kaitannya dengan market value perusahaan. Pemilihan metode akuntansi persediaan berdampak pada tingkat expected return oleh investor. Perusahaan yang menilai persediaannya dengan menggunakan metode LIFO akan memiliki tingkat expected return yang lebih kecil dibandingkan expected return perusahaan yang menggunakan metode non-LIFO.

\section{KESIMPULAN DAN SARAN}

\section{Kesimpulan}

Berdasarkan hasil analisis data analisis faktor-faktor yang mempengaruhi pemilihan metode akuntansi persediaan pada perusahaan Manufaktur yang terdaftar di Bursa Efek Indonesia (BEI) dapat disimpulkan bahwa:

a. Struktur kepemilikan, ukuran perusahaan, variabilitas persediaan, intensitas persediaan dan intensitas modal perusahaan manufacturing yang terdaftar di Bursa Efek Indonesia (BEI) berpengaruh secara signifikan terhadap metode akuntasi persediaan jika pengujian dilakukan secara serempak (uji-F). Hal ini diindikasikan oleh sig-p $=0.02$, lebih besar dari sig- $\alpha(0.05)$. Tetapi, jika pengujian dilakukan secara parsial dengan uji-t, terbukti bahwa hanya 3 dari 5 variabel bebas (yakni struktur pemilikan, variabilitas persediaan dan intensitas persediaan) yang berpengaruh signifikan terhadap variabel terikat 
(metode akuntansi persediaan). Hal ini diindikasikan oleh nilai sig-p ketiga variabel bebas tersebut lebih kecil dari sig- $\alpha(0.05)$.

b. Ada perbedaan signifikan antara metode akuntansi persediaan FIFO dengan metode rata-rata dilihat dari struktur kepemilikan dan ukuran perusahaan. Hal ini diindikasikan oleh nilai sig-(2-tailed) Levene Test $<0.05$, tetapi tidak ada perbedaan signifikan antara metode akuntansi persediaan FIFO dengan metode rata-rata dilihat dari variabilitas persediaan, intensitas persediaan dan intensitas modal. Hal ini diindikasikan oleh nilai sig-(2-tailed) Levene Test $>0.05$

\section{Saran}

Disarankan bagi para menejer atau pemilik perusahaan agar dapat mempertimbangkan factor-faktor dalam pemilihan metode persediaan.

\section{DAFTAR PUSTAKA}

Bar- Yoseef S dan P.K. Sen. 1992. On Optimal Choice of Inventory Accounting Method. The Accounting Review (67, April): p. 320336.

Biddle., G.C. 1980. Accounting Methods and Decision: The Case of Inventory Costing and Inventory Policy. Journal of Accunting Research: hal 355-366.

Cushing B.E. dan M.J Lee Clere. 1992. Evidence on the Dermation of Inventory Accounting Policy Choice. The Accounting Review 67 (April), hal 355-366.

Deliarnov. 2006. Ekonimi Politik. Pekanbaru. Penerbit Erlangga, Indonesiaa.

Dopuch N dan Pincus M. 1988. Evidence on the Choice of Inventory Accounting Method : LIFO versus FIFO. Journal of Accounting Research 26 (Spring) hal 28-59

Guardi. 1998. Akuntansi Pajak. Jakarta. Penerbit Gramedia,Indonesia

Hendriksen, Eldon S and Breda, Michael F. 1992. Accounting Theory. Richard D.Irwin, fifth edition

Horgn dan Ching Kuo. 1993. How do Small Firm Make Inventory Accounting Choice. Journal of Business, Finance and Accounting (April), hal 373-392

Ikatan akuntan Indonesia. 2004. Pernyataan Standar Akuntansi Keuangan. Jakarta: Penerbit Salemba Empat.

Mukhlasin. 2001. Analisis Pemilihan Metode Akuntansi Persediaan Dan Dampaknya Terhadap Earning Price Ratio.Tesis S2. UNDIP. 
Jain, B.A.Shehar,C, and Torbey,V. 2003. Determinants of Devidend Initiation by IPO Issuing Firm, Journal of Banking and Finance 23:1-31

Jehsen, M.C.and Meckling, W.H. 1974.Theory of the Frim: Menagerial Behavior,Agency Cost and Ownership Structure,Journal of Financial Economics, 3: 305-360

Kieso D.E dan J.Weygant. 1995. Int.Accounting $8^{\text {th }}$ ed. New York, Jhon Willey \& Sons Inc

Salma Taqwa. 2001. Faktor-faktor Yang Mempengaruhi Pemilihan Metode Akuntansi Persediaan Pada Perusahaan Manufaktur Di BEI.Tesis S2, UNDIP. 